\title{
浅水状態の栈粗度乱流場における水面変動の パターン変化に関する画像計測による検討 PATTERN CHANGE OF WATER SURFACE VARIATION OF STRIP ROUGHNESS TURBULENCE IN SHALLOW WATER CONDITIONS BY USING IMAGE ANALYSIS TECHNIQUES
}

\author{
谷昂二郎 $1 \cdot$ 藤田一郎 $2 \cdot$ 能登谷祐一 1 \\ Kojiro TANI, Ichiro FUJITA and Yuichi NOTOYA \\ 1学生会員 神戸大学大学院工学研究科（ 657-8501 神戸市灘区六甲台町1-1） \\ 2正会員 学術博 神戸大学大学院教授 工学研究科（=657-8501 神戸市灘区六甲台町1-1）
}

\begin{abstract}
In shallow water conditions, open-channel flows are subject to the influence of channel bottom roughness because the boundary layer or vortices generated at the bottom interact with water surface. Such an influence become more pronounced when the bottom is composed of discrete roughness such as a strip roughness. In the present study, water surface variations were investigated experimentally by varying the water depth relative to the roughness height. Although the water surface is kept almost horizontal for a relatively large depth of water, it tends to show significant differences with decrease of water depth. As an example, the water surface exhibits three dimensional topographical features with various arrangement of lumps depending on hydraulic conditions. Moreover, water surface begins to oscillate quite periodically with a hydraulic jump under specific hydraulic conditions. A new image analysis technique was developed to capture such surface flow features.
\end{abstract}

Key Words : shallow flow, strip roughness, image analysis, flow visualization, PIV

\section{1. まえがき}

開水路の水面は大気と流水を境とする気液界面を構成 しており，気層側からの影響や液相側からの影響によっ てその形状は自由に変形する. 気層側からの影響で最も 主要なのは言うまでもなく気流の影響であり, 風速や風 向によって水面には多種多様な風波が発生し, それが内 部の乱流場に影響を及ぼす ${ }^{1,2)}$. 液相側からの影響には, 開水路乱流が果たす役割が大部分であるが，底面の境界 層から発生する渦構造が水面に及んで水面変動を与える 場合3,4)や底面に配置された個々の粗度要素における形状 抵抗による影響が水面にまでおよび水面を変形させる場 合5)などが考えられる。また，水面に現れる波紋に関す る力学的な考察も行われている6.

一方，洪水中の実河川の水表面を観察していると，風 がほとんどない場合でも水面に白波が立っていることが 多いことに気づく. 観察対象となる洪水流は通常は常流 状態であるため, 水理学の教科書的には白波を伴う局所 的な水面形状が発生するはずはないが，実際には頻繁な 白波の発生を確認することができる。これは，底面から の大規模乱流が水面に衝突することにより局所的に水面 変動が発生し，そこで発生した波の頂部の進行速度の方
が早くなるため, 条件によっては局所的に小規模な砕波 が発生した結果と考えられる. あるいは，河床に比較的 大きな岩などがあるとその頂部付近で，白波を伴った， 周期性のある興味深い水面変動が観察される場合もある. この場合は, 岩頂部から水面までの距離が比較的短いた め, 岩による抗力による影響が直接, 水面変動に大きく 関与しているものと考えられる.いずれにしても，水面 下の液相側で発生する様々な要因が水面変動を多様なも のにしている. このような著しい水面現象は河床面が滑 面の場合には，高レイノルズ数になっても発生するとは 考えにくい.

以上のような粗面乱流の水面変動場への影響について これまで著者らは，人工粗度や砂礫，あるいは栈粗度を 対象とした実験的あるいは数值解析的な研究を進めてき た ${ }^{3,5,7-12)}$. これまでの研究は浅水状態ではあっても水面 形状が大きく変化するほどの水理条件は対象にしてこな かったが，本研究では比較的粗度間隔の大きな栈粗度を 対象とし, 粗度要素の数倍程度の水深において発生する 水面変動について実験的な検討を行った. 実験は可視化 画像解析を中心に行ったが，大規模に変動する水面形を 効率的に捕捉する新たな計測法や水面変動の面的なパ ターンを簡易的に可視化する新たな手法を開発した。ま 
表 1 水理条件（*は参考値）

\begin{tabular}{|c|c|c|c|c|c|c|c|c|c|c|c|c|c|}
\hline CASE & $\begin{array}{c}\text { Water } \\
\text { depth } \\
h_{n} / k \\
(-)\end{array}$ & $\begin{array}{c}\text { Water } \\
\text { depth } \\
h_{k} / k \\
(-)\end{array}$ & $\begin{array}{c}\text { Mean } \\
\text { velocity } \\
u_{m} \\
(\mathrm{~cm} / \mathrm{s})\end{array}$ & $\begin{array}{c}\text { Mean } \\
\text { velocity } \\
u_{k} \\
(\mathrm{~cm} / \mathrm{s})\end{array}$ & $\begin{array}{c}\text { Froude } \\
\text { number } \\
F r_{m}(-)\end{array}$ & $\begin{array}{c}\text { Froude } \\
\text { number } \\
F r_{k}(-)\end{array}$ & $\begin{array}{c}\text { Reynolds } \\
\text { number } \\
\operatorname{Re}(-)\end{array}$ & $\begin{array}{c}\text { Roughness } \\
\text { height } \\
k(\mathrm{~cm})\end{array}$ & $\begin{array}{c}\text { Relative } \\
\text { roughness } \\
\text { spacing } \\
L k(-)\end{array}$ & $\begin{array}{c}\text { Cannel } \\
\text { slope } \\
I(-)\end{array}$ & $\begin{array}{c}\text { Oscillation } \\
\text { frequency } \\
f(\mathrm{~Hz})\end{array}$ & $\begin{array}{c}\text { Strouhal } \\
\text { number } \\
\text { St (-) }\end{array}$ & $\begin{array}{c}\text { Water } \\
\text { surface } \\
\text { profile }\end{array}$ \\
\hline Case1 & 3.02 & 2.09 & 26.5 & 38.3 & 0.51 & 0.89 & 7222 & \multirow{8}{*}{0.9} & \multirow{8}{*}{20} & \multirow{8}{*}{0.02} & & & \multirow{2}{*}{$\begin{array}{c}\text { Steady } \\
\text { jump }\end{array}$} \\
\hline Case2 & 4.04 & 3.29 & 40.7 & 50.1 & 0.68 & 0.92 & 14833 & & & & & & \\
\hline Case3 & 4.10 & 3.37 & 41.6 & 50.8 & 0.69 & 0.93 & 15389 & & & & 1.50 & 0.0297 & \multirow{3}{*}{$\begin{array}{c}\text { Periodic } \\
\text { jump }\end{array}$} \\
\hline Case4 & 4.36 & 3.67 & 45.6 & 54.3 & 0.74 & 0.95 & 17889 & & & & 1.50 & 0.0249 & \\
\hline Case5 & 4.79 & 4.30 & 48.5 & 54.1 & 0.75 & 0.87 & 20944 & & & & 2.00 & 0.0332 & \\
\hline Case6 & 5.63 & 4.67 & 50.4 & 60.8 & 0.71 & 0.94 & 25556 & & & & & & \multirow{3}{*}{$\begin{array}{c}3 \mathrm{D} \\
\text { lumps }\end{array}$} \\
\hline Case7 & $6.10^{*}$ & & 55.7 & & 0.76 & & 30556 & & & & - & - & \\
\hline Case8 & $7.20^{*}$ & - & 58.3 & - & 0.73 & - & 37778 & & & & & & \\
\hline Case9 & - & 3.33 & - & 41.6 & - & 0.94 & 8333 & 0.6 & 20 & 0.02 & 2.29 & 0.0329 & $\begin{array}{c}\text { Periodic } \\
\text { jump }\end{array}$ \\
\hline
\end{tabular}

た，実験の遂行時に見出した非常に周期性の高い水面の 振動現象に着目して詳細な検討を行った。

\section{2. 実験方法}

\section{（1）実験装置の概要および水理条件}

実験には長さ $6 \mathrm{~m}$, 幅 $0.3 \mathrm{~m}$ で可変勾配式の直線開水路を 用いた．水路は全面ガラスであらゆる方向から流れの可 視化観測が可能である. 水路底面には，一辺が $k=0.9 \mathrm{~cm}$ の正方形断面の栈粗度を等間隔 $L$ （粗度の先端から次の 粗度の先端までの距離) で敷き詰めた。ここで相対粗度

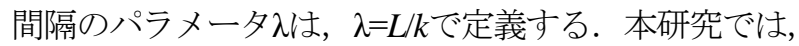
$\lambda=20$ とした．この間隔は通常の栈粗度としては大きな值 であるが，相対水深が小さい場合に後述する振動現象の 発生を見出したため, 今回の実験ではこの相対粗度間隔 を基本とした。 なお，栈粗度としては，比較のために $k=0.6 \mathrm{~cm}$ ののも別途使用した. 水理条件は表-1に示す 通りであるが，本研究で対象とする流れ場の多くでは水 面が平坦ではないため, 粗度要素真上の平均水深 $h_{k}$ なら びに粗度区間の平均水深 $h_{\mathrm{m}}$ を定義した．フルード数は各 水深をスケールとする $F r_{\mathrm{k}}, F r_{\mathrm{m}}$ の 2 通りを定義した。 た だし, Case7およびCase8では, 水面の横断方向の起伏が 大きく, 後述の画像計測による水面位置の推定が困難で あったため, 数点における水深の平均值を参考值として 示した. また, レイノルズ数ReはRe $=q / v$ として算出 した. $q$ は単位幅流量, vは動粘性係数である.

\section{(2) 可視化画像の取得法}

計測方法の概要図を図-1に示寸．流れや水面の観測計 測は以下の 2 通りの方法で行った。第 1 の計測は縦断面 内の流速と水面形の同時計測で，水路の下方から水路中 央の縦断面内に照射したアルゴンイオンレーザー光膜内 の流れ場は水路横に設置した高速度カメラ(DETECT製, HAS500)で撮影した. トレーサーとしては平均粒径が約 $50 \mu \mathrm{m}$ のナイロン破砕粒子を混入させている. 水面形は 先述のカメラに同期させた高速度カメラ (DETECT製,

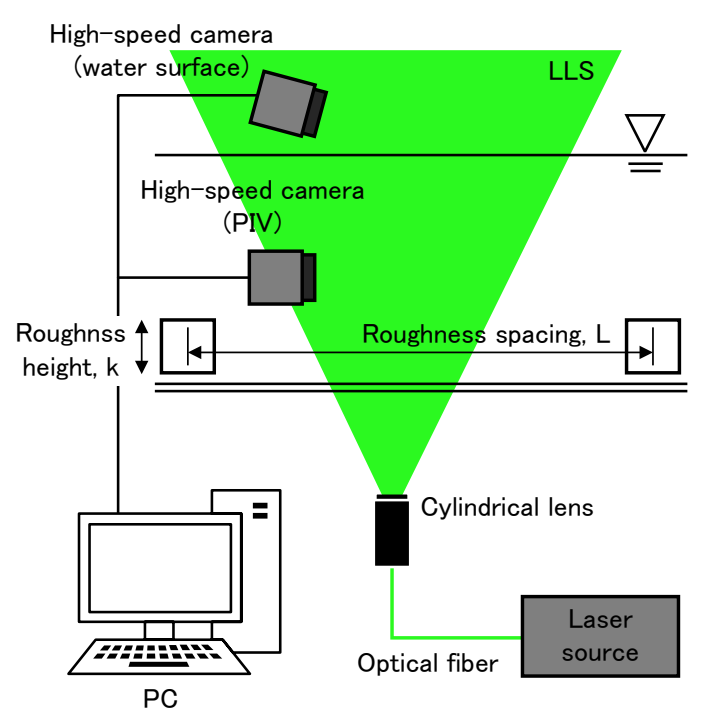

図-1 実験装置概要

HAS550)を水路の斜め上から水面を見下ろすようなアン グルで設置し，レーザー光膜が水面と交差する状況を同 時撮影した.

第 2 の計測は平面的な水面変動を把握するために行っ たものである.この場合は，ハイビジョンビデオカメラ (Sony, HDR-CX720)を水路の真上に取り付け, カメラ 側から下流側に向けて照射した強力なLEDライトの反射 光が散乱する様子を撮影した．本来なら，ステレオ計測 などにより，詳細な二次元水面変動場を計測するのが良 いが，本実験では水面変動のパターンを分類する目的で 今回の簡便な方法12)を採用した。

\section{3. 水面形の検出方法}

従来, 水面形の検出方法としては様々な手法が提案さ れてきている．一般的には，レーザー誘起蛍光法(LIF)や 輝度変化で水面を検出する方法13)などがある. 本研究で 使用したのは後者の方法であり, 以下で説明する手法 のうちMethod Cを採用したが，比較のためにこれまでに 開発してきた手法も示す. 

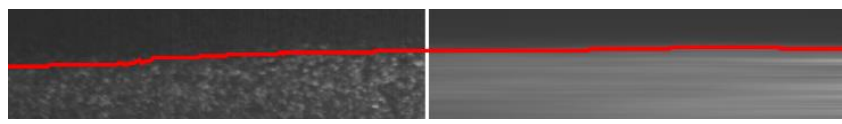

Method $\mathrm{A}$ (左 : 撮影画像, 右 : 10枚多重合成+ブラ一)
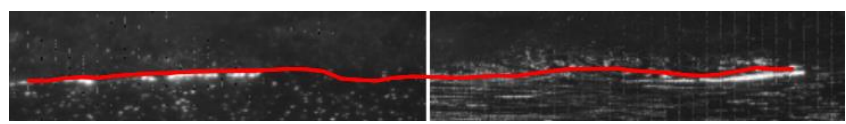

Method B(左 : 撮影画像，右 : 10枚多重合成)

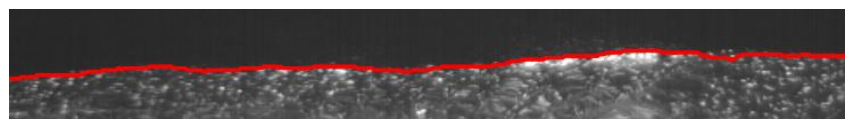

Method C

(a) 平坦な場合

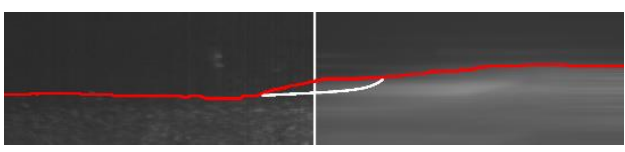

Method $\mathrm{A}$ (左 : 撮影画像, 右 : 10 枚多重合成+ブラ一)

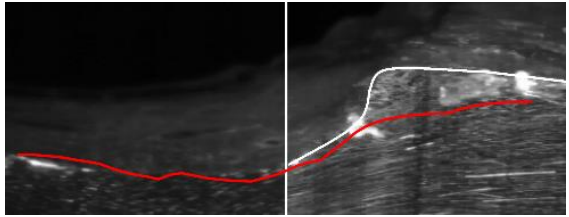

Method B(左：撮影画像，右：10 枚多重合成)

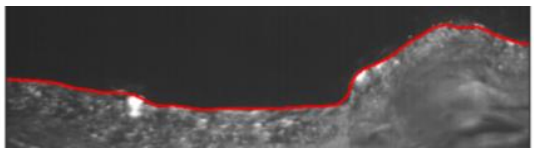

Method C

(b) 大変形する場合

図-2 各検出法の比較（赤線 : 各手法による推定値，白線：目視による推定値）

\section{(1) 水平方向平滑化を用いる方法 (Method A)}

この手法は岡西ら ${ }^{12}$ が用いた方法で，詳細は文献に譲 るが，基本的には水面における輝度変化が十分でないと きに使える手法である．水面の直上に配置したミラーを 通して見た水面の画像を10枚程度多重合成，次にそれを 横方向に平滑化し(ブラー処理), 輝度変化を強調した後 に二值化して水面を検出する．10枚の画像合成では水面 形状も多重化されて形がぼやける危険性もあるが，実際 の画像サンプリングは $500 \mathrm{~Hz}$ 程度であり，本実験の範囲 では，10枚すなわち0.02秒間の水面の変形量は無視でき る程度である。

\section{(2) 粒子画像の輝度勾配を用いる方法 (Method B)}

この手法は流速計測にも用いる粒子画像をそのまま使 用し，一台のカメラのみを用いる点が異なる．10枚程度 の連続画像を多重合成するとトレーサ一粒子の軌跡が横 方向に連なる画像が得られる. 水面より上にはトレー サーは存在しないため, 鉛直方向の輝度勾配を用いた次 式により，水面の位置を明確に識別できる9).

$$
J_{22}(x, y)=\int_{A} \frac{\partial g}{\partial y} \frac{\partial g}{\partial y} d A
$$

ここに, $g(x, y)$ は画像上の輝度分布， $x y$ はそれぞれ画 像の横方向と縦方向の座標軸, A は縦方向の輝度勾配の 二乗值を局所的に積分するテンプレートサイズである. $A$ の值は, 通常30x10pixel程度とする. $J_{22}$ の值が縦方向 に急減する位置が水面に一致する.

\section{（3）界面の輝度変化を高精度に検出する方法（Method C)}

図-1で説明したように，同期させた 2 台の高速度カメ ラを用いる. これは, 水面が大変形する場合, 内部から では変形の様子を十分に撮影できない状況が発生したた めである. 水面の検出は, 以下の手順でノイズ除去を行
いながら行う。まず，画像全体の輝度範囲を界面付近の 輝度変化が顕著となるようにコントラストを調整する. 次に，画像の平均輝度值を用いて画像を二值化する. 界 面にはノイズが残留するため, 15x15pixel程度の検出 ウィンドウ $A$ 想定し， ウィンドウ内の二值化された輝 度値 $b\left(x^{\prime}, y^{\prime}\right)$ の合計 $S$ を次式より計算し,

$$
S(x, y)=\int_{A} b\left(x^{\prime}, y^{\prime}\right) d A
$$

以下の判断基準によって, 二值化輝度值の修正を行う.

$$
b(x, y)=\left\{\begin{array}{lll}
1 & \text { for } & S(x, y)>A / 2 \\
0 & \text { for } & S(x, y) \leq A / 2
\end{array}\right.
$$

この処理によって, 界面のノイズを平滑化できる.

\section{（4）各水面検出手法の比較}

以上に示した 3 通りの方法で水面を検出した結果を水 面が平坦な場合と大変形した場合に対してそれぞれ図-2 に比較した. 撮影した瞬間画像に重ねて，赤の実線で各 手法により推定された水面位置, および必要に応じて処 理過程の画像を示している. 水面が比較的平坦で水面に 沿った流れがある場合には，どの手法も良好に水面を検 出できている（図-2 (a)）。一方, 水面勾配が大きい場 合や，局所的に跳水が発生している場合は部分的に流れ が減速し，多重合成によってもトレーサーの軌跡が線状 とならないため, Method Bでは検出が難しくなっている

(図-2(b))。.Method Aでは，ミラーを通して見た画像 に散乱光によるノイズが入り込んでいるために水面の検 出はうまくできていない.これに対し，Method Cでは， 跳水渦のある場合でも良好に複雑な水面形状を捉えるこ とができている．したがって，以降の水面変動解析は Method Cにより行う. Method Cで検出される水面形状は, 流れ場の解析において液相内部の結果のみを抽出するこ とに活用した。 


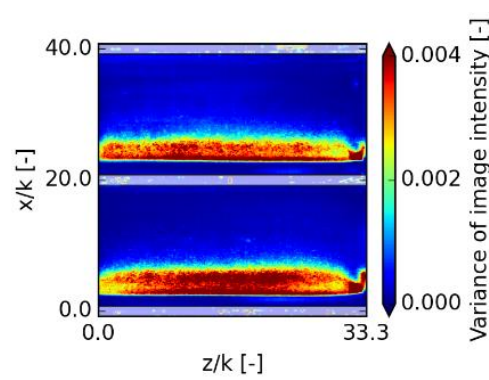

(a) Case1 $\left(h_{m} / k=3.02\right)$

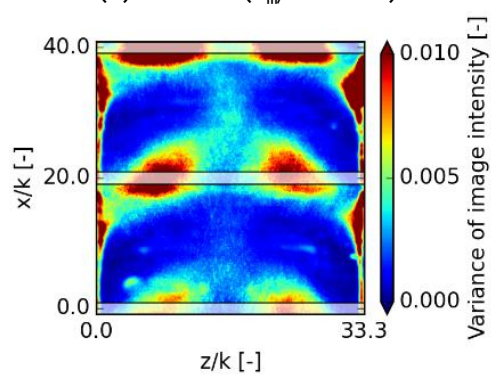

(d) $\operatorname{Case} 6\left(h_{m} / k=5.63\right)$

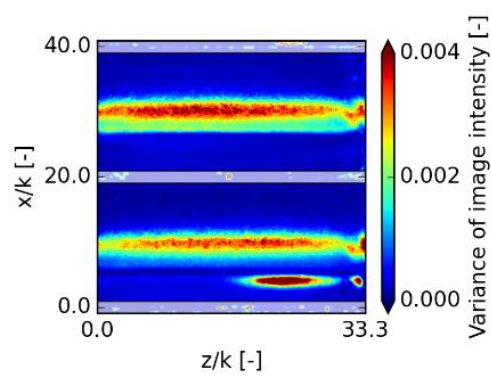

(b) Case2 $\left(h_{m} / k=4.04\right)$

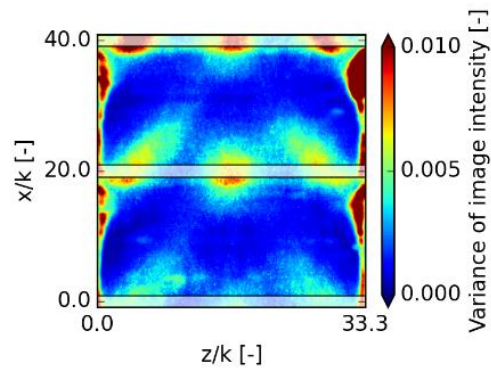

(e) Case7 $\left(\mathrm{h}_{\mathrm{m}} / \mathrm{k}=6.10\right)$

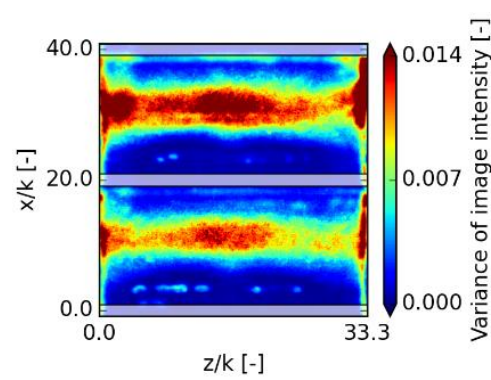

(c) Case4 $\left(h_{m} / k=4.36\right)$

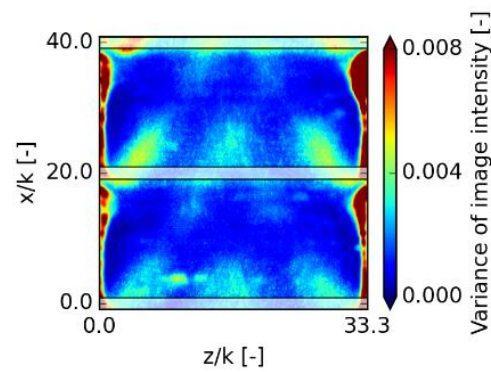

(f) Case $8\left(h_{m} / k=7.02\right)$

図-3 水面形の平面パターン $(x$ : 流下方向, $\mathrm{z}$ : 水路横断方向 $)$

\section{(5) 平面的な水面パターンの検出手法}

ここでは，2(2) で説明した手法で得られた画像の処理 法について記す．基本的には，水面勾配が局所的に変化 したり変動が大きい場合には，水面からの反射光が大き く摇らぐことを利用する．即ち，輝度值の分散を水面の 各点について求めることにより，水面に現れた特徽的な パターンの再現を試みた．図-3に検出例を示寸が，水理 条件によって水面のパターンが大きく変化していること がわかる. 図では, 斜め撮影した画像を真上からのアン グルに幾何補正している.

\section{4. 結果と考察}

以下では，相対粗度間隔を一定に保ったまま，供給流 量（レイノルズ数）を徐々に増大させ，粗度要素に対す る相対水深 $h_{\mathrm{m}} / k$ を3.0から7.0程度まで変化させたときの 水面のパターンと縦断流速場を比較する。 なお, 流れ場 の計測には3連続画像を使い，時空間微分法 ${ }^{14)}$ の適用に より精度を高めたPIV(Particle Image Velocimetry)を使用し た. PIVソフトウェアは，GPUを利用して内容を大幅に 書き換えることにより，従来よりも50倍以上の高速化を 実現した. ケースによっては波高が三次元的に大きく変 動し，一方向からの撮影では内部の粒子画像を正しく取 得できなかったため，PIV計測はCase1からCase5のみで 実施した。

\section{（1）水面変動のパターン変化}

平面的な水面形のパターン変化については, 図-3にす でに示している. 相対水深が最も小さいCase1では, 個々の栈粗度を越流した流れが局所的に跳水を発生させ ている.この状況は粗度間隔を更に大きくしても変わら

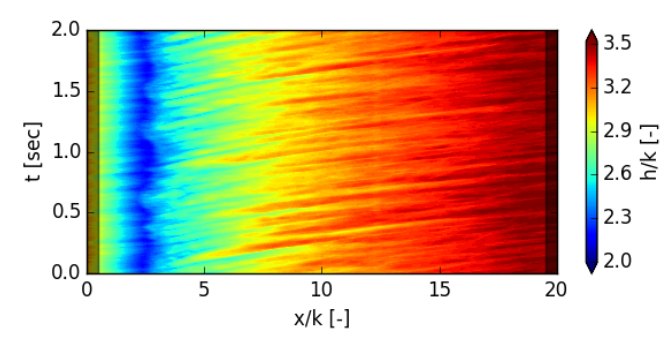

(a) Case1 $\left(h_{m} / k=3.02\right)$

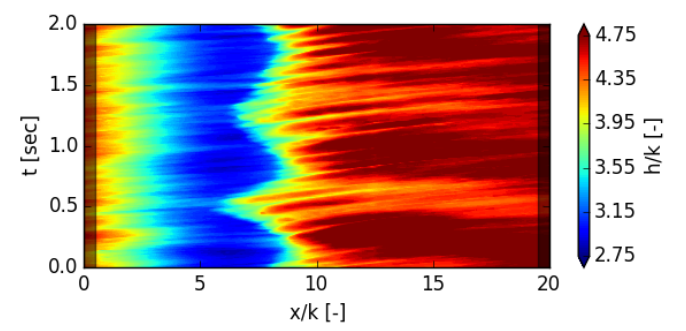

(b) Case3 $\left(h_{m} / k=4.10\right)$

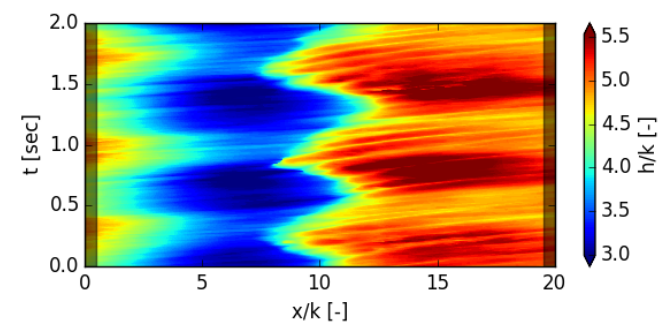

(c) Case4 $\left(h_{m} / k=4.36\right)$

図-4 水面形の時空間プロット

ず，下流側の粗度の影響は，水深の堰上げを除けば受け ていない. レイノルズ数を増大させていくと, 発生して いる跳水が，下流で堰上げられた流体塊と干渉して摇ら ぎだす，これに相当するのがCase3であり，画像計測さ れた縦断面の水面形の時空間プロットを示した図-4 (b) 


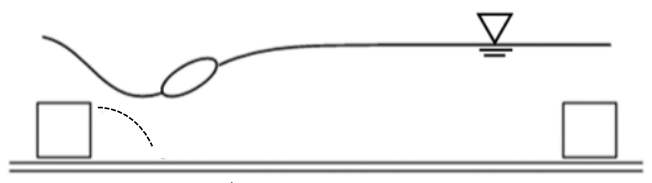

a) Steady jump

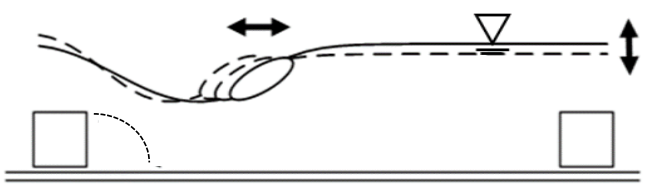

(b) Periodic jump

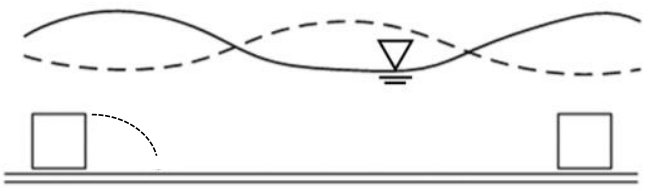

(c) 3D lumps

図-5 栈粗度流れの水面形変化

では， $x / k=7$ から10の範囲で摇らぎ始めていることがわ かる. Case3からわずかにレイノルズ数を増大させた Case4で発生したのが規則的な跳水の振動現象である.

図-4(c) に示すように， $x / k=8$ から 12 の範囲で周期的な跳 水が発生している。この流況はCase5の条件まで続くが, さらにレイノルズ数を増大させると, 跳水が消えると共 に，水面の横断方向の変形が目立つようになる. 即ち, 局所的な水塊のコブ状の盛り上がり (lump)が並んで発生 するが，興味深いことにそのコブは，レイノルズ数の増 大につれて数を増す. その様子は図-3からもわかるが, Case6では二個だったものが, Case7では三個, Case8で はそれ以上に増えている. このような三次元的な水面変 形は，側壁と栈粗度のつなぎ目で発生する局所流だけで はなく，横断方向の内部流の影響と思われるが，その発 生要因については今後の検討が必要である.

以上のレイノルズ数 (流量) の変化に伴う一連の水面 変形の様子をスケッチしたのが図-5である.このように, 間隔の大きな栈粗度流れでは, 浅水状態において多用な 水面形が発生することがわかる.

\section{（2）水面変動の周期性}

ここでは，Case4などで生じた振動跳水に関する考察 を行うために，周波数 数Stを次式で定義する.

$$
S t=\frac{f k}{u_{k}}
$$

振動の周波数は水位変動の時系列データに関する卓越周 波数から推定した. また，スケール効果を調べるために， $k=0.6 \mathrm{~cm}$ 粗度要素を用いて, 周波数を求めたところ, 表-1にも示寸ように，ストローハル数は一貫して 0.03 程 度となることがわかった。

\section{（3）鉛直断面内の流速場}

PIV計測で得られた縦断面内の主流速分布の例を図-6

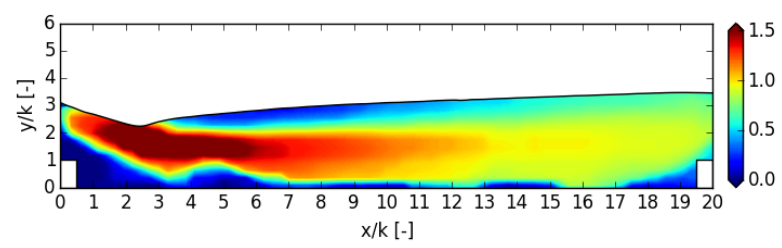

(a) Case1

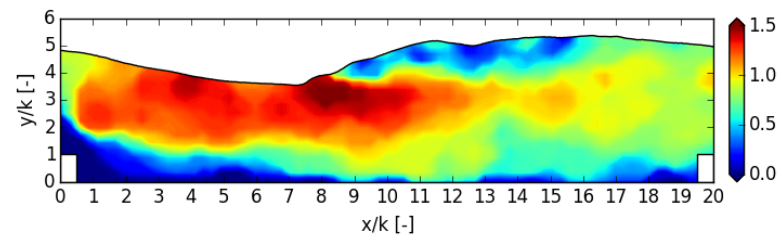

(b) Case4, $\mathrm{T}=\pi / 2$

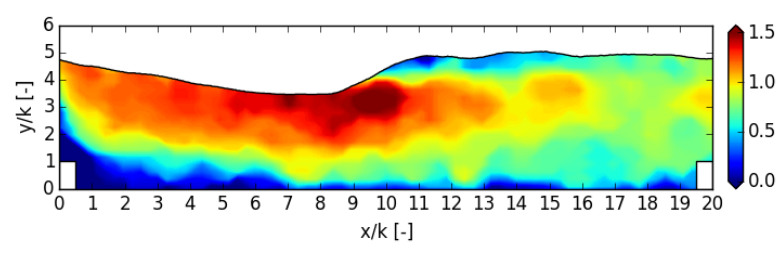

(c) Case4, $\mathrm{T}=\pi$

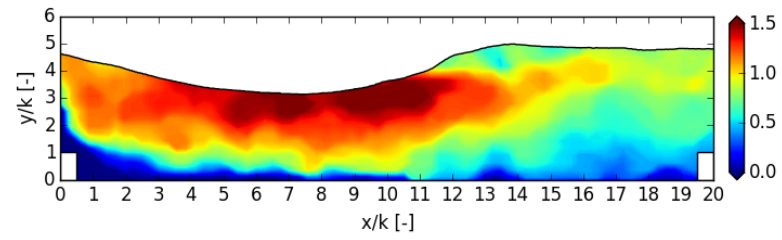

(d) Case4, $T=3 \pi / 2$

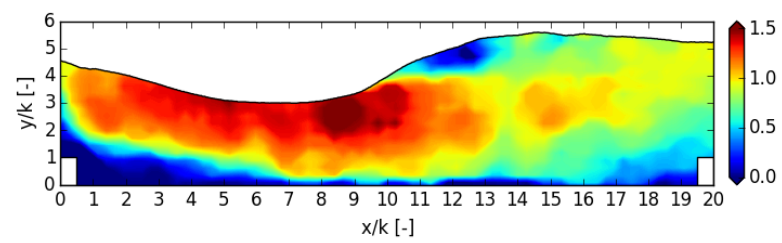

(e) Case4, $\mathrm{T}=2 \pi$

図-6 平均主流速分布 $\left(\mathrm{u} / \mathrm{u}_{\mathrm{m}}\right)$

に示す. Case1では，栈粗度下流で発生する跳水部分を 含めた流速分布が良好に得られている. Case4の振動跳 水については, $T=\pi / 2, \pi, 3 \pi / 2,2 \pi$ の各位相で平均した 值を示す. $T=\pi / 2$ として示したのは跳水が最も上流に達 する位相である。 このとき，下流側粗度前面の流速は他 の位相に比べ大きくなっている． $T=\pi て ゙ は$ 跳水が下流側 に移動しだすと共に下流側の水位が低下する. 即ち粗度 間の流体容積は減少傾向となる. $T=3 \pi / 2$ は $T=2 \pi$ とへの遷 移状態である. $T=2 \pi$ では下流側粗度前面に低流速域が発 達するとともに，水位も上昇している．Case4ではこの ような跳水の前後の移動と下流側水位の変動が連動し生 じている.このことは図-5(b)にも示した．このような 振動跳水が発生寸る原因は不明だが，粗度間隔や下流側 粗度の形状抵抗の時間変化が一つのファクターと考えら れる. また, 定常な跳水が発生しているCase 1 と比較す ると, Case1でも下流側の粗度での堰上げは確認できる ものの, 跳水位置から十分離れた $x / k=13$ 付近で, 流速は 概ね一様になっている。 そのため, Case4のような振動 現象には至らないが，先に図-3(a)-(b)で示しているよ 


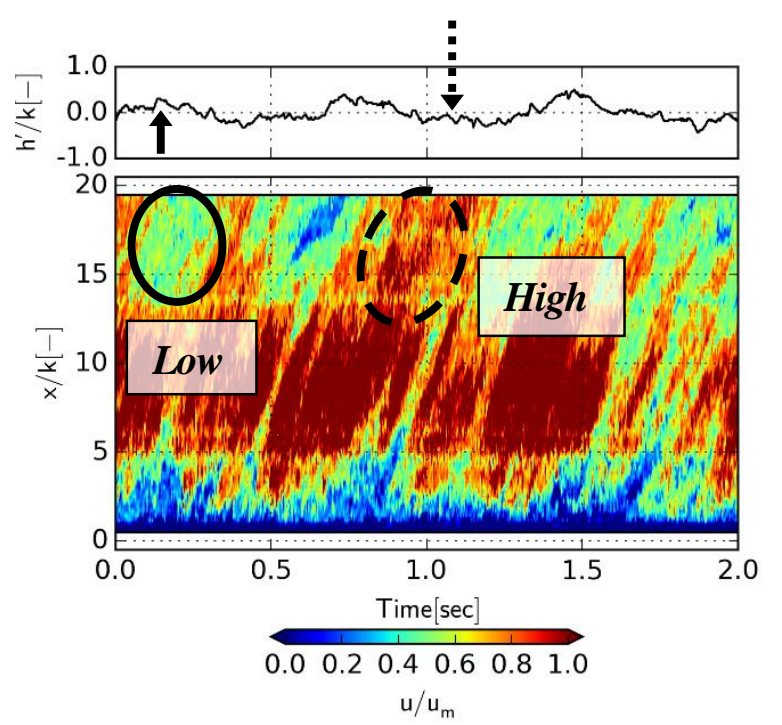

図-7 CASE4，水位変動の時系列 $(\mathrm{x} / \mathrm{k}=20)$ および 主流速の時空間プロット $(\mathrm{y} / \mathrm{k}=1)$

うに，レイノルズ数の増大に伴って越流水深が大きくな るにつれ，跳水位置は下流へと移動しており，跳水位置 がある範囲に達したときに，先述のような下流側の粗度 との干渉を起こし，振動に至るものと考えられる.

以上に述べた振動跳水時の内部流速と水位変動の関係 について，時系列データにより更に詳細に検討寸る．図 $-7 に y / k=1$ の断面における主流速の時空間プロットと $x / k=20$, 即ち下流側粗度真上の水位変動の時系列を示す. 下流側の粗度前面に間久的な低流速域が確認できるが, 水位変動にある程度対応していることがわかる．すなわ ち，下流側粗度上で水位が上昇している時には粗度前面 の低流速域が広がる（図中実線）。また，粗度上の水位 変動が負に転じると, 粗度間中央付近に見られる, 断面 上の最大流速を有する流体塊が粗度前面にまで流れ込ん でいる（図中破線）。これらの様子は，先述の位相平均 した流れ場からの考察とも矛盾なく対応している.

\section{5. あとがき}

本研究では, 相対粗度間隔の大きな栈粗度粗面に, 相 対的に小さな水深で流れを生じさせた場合について，実 験的な検討を行った．その結果，水面の平面形状は底面 近くの流れの影響を強く受けて三次元的に変化し，その モードも水深，あるいはレイノルズ数に応じて大きく変 化することを，新たな水面の可視化手法の導入により明 らかにした。 さらに，これまでに報告されていない非常 に特徵的な振動跳水が発生することを見出し，その内部 構造や発生条件, 振動現象のストローハル数について新 たな知見を得た. 本研究で対象とした多様な平面形状を 持つ流れは, 洪水時の水面にも部分的に現れるものであ る．まえがきでも述べたように，実河川でも水面が振動 している場合があるが，振動は巨岩上を水が流れる場合 に発生することが多いようである，今後は，本実験に対 する三次元数值解析を行い, 最もクリティカルなケース として振動跳水の再現計算を試みる予定である.

\section{参考文献}

1) 禰津, 山上, 岡本 : 風波・植生開水路流れの組織乱流構造に 関寸る実験的研究, 応用力学論文集, Vol. 10, pp.795-802, 2007.

2) Borue, V. Orszag, S. A. and Staroselsky, I. : Interaction of surface waves with turbulence: direct numerical simulations of turbulent open-channel, J. Fluid Mech. ,vol. 286, pp.1-23,1995.

3) 小田崇裕・藤田一郎・吉村英人・岡西健史 : 粗面開水路乱 流の水面変動に及ぼす乱流渦構造の条件付き抽出に関する研 究，土木学会論文集B1（水工学）,Vol.70, No.4, I_823-I_828, 2014.

4) Horoshenkov, K.V., et al. : The pattern of surface waves in a shallow free surface flow, Journal of Geophysical Research: Earth Surface Vol.118, No.3, pp.1864-1876, 2013.

5) Fujita, I., Okanishi, T. and Furutani, Y. : Simulation of shallow water surface patterns with hemisphere roughness elements by large eddy simulation, 3rd International Symposium on Shallow Flows (ISSF), 57P, 9pages on CDROM, 2012.

6) Brocchini, M. and Peregrine, D. H. : The dynamics of strong turbulence at free surfaces part 1: Description, J. Fluid Mech. Vol.449, pp.225-254, 2001.

7) Fujita, I. and Okanishi, T. : New method for visualizing large scale turbulence structure by tracing sheet of pseudo-tracer cloud, The 15th International Symposium on Flow Visualization (ISFV15), ISFV15-046 S20, on CD-ROM, 2012.

8) Fujita, I., Okanishi, T. and Oda, T. : Simulation of open-channel turbulence with gravel bed by LES, International Conference on Simulation Technology(JSST2012), JSST2012_OS2-1.pdf, on USB memory, 2012.

9) Ogami,A.,Fujita, I. and Yoshimura, H. : Simultaneous measurement of water surface fluctuation and internal velocity field of open channel flow with strip roughness,Korea-Japan Joint Seminar on Dynamic Measurements for Multi-scales \& Multi-physics, on USB memory, 2014.

10) 吉村英人・藤田一郎：水面変動を考慮した粗面乱流場の LESおよびPIVによる解析,水工学論文集, 52巻, pp.1015-1020, 2008.

11) 古谷勇樹・藤田一郎：埋め込み境界型LESを用いた半球粗 面乱流場における水面変動と移流特性に関する検討,水工学論 文集, 55巻, pp. S 1027-S 1032, 2011.

12) 岡西健史・藤田一郎・古谷勇樹 : 半球粗度粗面が生成する 水面形のパターン分類とその特性に関する基礎研究,土木学会 論文集B1(水工学),Vol.68, No.4, I_1279-I_1284, 2012.

13）宮本仁志・神田徹・大江和正 : 画像解析による水面変動・ 流速の同時計測法と開水路凹部流れへの適用,水工学論文 集,45巻, pp.511-516, 2001.

14) 藤田一郎 : 時空間微分法に基づく高精度PIVの開発, 水工学 論文集,48巻,pp.721-726, 2004.

(2015.9.30受付) 